\title{
Perceptions on language testing and assessment: A Case study of B.Ed students' in Nepal
}

\author{
Mani Ram Sharma* \\ Mahendra Ratna Campus (TU), Tahachal, Kathmandu, Nepal
}

\section{Keywords \\ Perception \\ Language testing \\ Assessment \\ Students \\ Nepal}

Received: 3 September 2019

Accepted: 13 November 2019

Published: 12 March 2020

\begin{abstract}
The major aim of the study is to explore students' perceptions of language assessment or testing. Testing is examining one's ability. Testing is an essential part of teaching and learning process; although, most often disliked. A number of researches have been conducted on issues on testing and assessment, such as wash-back effect and test anxiety. The paper tries to explore a group $(N=12)$ of B. Ed second year studying major English students in Mahendra Ratna Campus, (TU) Tahachal, Kathamndu, Nepal and their' perceptions about language testing and assessment. A qualitative approach with the case study method is being utilized. The findings of the study reveal that collectively students are well aware of the purposes of assessment. However, their experiences with assessment describe cases of language assessment. They indicate several issues in improving the effective testing strategies that indicate room for improvement in the field of assessment in this techno-friendly context.
\end{abstract}

\section{INTRODUCTION}

Simply speaking, language testing refers to a Language testing refers to the process of measuring instrument designed to elicit a specific sample of an individual's behavior. A test is also used as device to compare an individual with other individuals who belongs to the same group, educational status and age. Assessment is an inseparable part of English language learning-teaching. It is defined as "any act of interpreting information about student performance, collected through any of a multitude of means" (Brown \& Hirschfeld, 2008; Hilao, 2016). Testing is a term that is not always used precisely. it refers to the specific procedures a that teachers and examiners employ to try to measure ability in the language using what learners show they know as a indicator of their ability. Language testing and teaching are closely related. Therefore, there is reciprocal relationship between language teaching and testing.

The appearance of language testing journal in 1983 was an important landmark in the history of language testing
(Khaniya, 2005; Wu, 2017) which offered for the first time, good forum for language testing researchers to bring out their research interests. He further says language testing is widely accepted that it offers useful inputs to the teachers to be aware of the effect of teaching, and also some insight on whether he should continue the way he teachers or change it in order to make his teaching more effective. Let us observe some of the definitions given by distinguished scalars. Heaton (1975) has defined testing conceiting with teaching as they are inseparable part of each other. He says, "Testing and teaching are so closely interrelated that virtually impossible to work in either field without being constantly concerned with other." Here, he meant that, the teaching is influenced by testing and vice versa. On the other hand, (Khaniya, 2005) has defined test as a process of scrutinizing how far learners have learned what the teacher wishes them to learn. Huges (1995) says "the proper relationship between teaching and testing is surely that of partnership. " Testing is a means of checking whether the desired objec-

\footnotetext{
* corresponding author: Mani Ram Sharma

†email: smaniram125@gmail.com
} 
tives to attain have been achieved or not, Tests, in language teaching arte the means of measuring the effectiveness of a teaching and learning program, students progress and their performance that is to says, tests function as a measuring instrument in the education system that checks the extent to which the learners have achieved the materials taught and how successful the teaching has become. In the past, was beloved that teaching was enough to obtain the prior decided objectives of language education. Later, testing was taken as a compulsory to teaching. Then teaching and testing began side by side.

\section{Background of the Study}

In the past, language testing was understood as a part of applied linguistics and language teaching. Later on language testing was recognized as a course of study under applied linguistics. Now, many universities and colleges have started teaching language testing as a separate subject. So language has been separate and independent discipline. Testing has become an international activity and disciplines itself. Testing in a broad sense has always been an inherent part of teaching (De Jong, 2018). Assessment as an ongoing process through which student's learning is not only monitored but in which students are involved in making decisions about the degree to which performance matching their ability. A test is seen as a natural extension of classroom work providing teacher and student with useful information that can serve each as basis for improvement a test can defined as a method of measuring the learner's ability knowledge to determine their level of development and assessing qualitatively how far they have prepared themselves in a given area. Now language testing can be treated as a vivid panorama of the testing as an independent discipline which is so nicely interwoven with teaching and learning. language education cover the areas of both teaching and learning when there comes the question of teaching and learning, testing comes automatically within it. It is mainly because of their complementary nature. Teaching without testing and assessment does not tell about the effectiveness of teaching learning activities where testing without teaching is meaningless. So these terms are intertwined.

Assessment is an inseparable part of English language learning-teaching. It is defined as "any act of interpreting information about student performance, collected through any of a multitude of means" (Brown \& Hirschfeld, 2008). It is a test which gives clear pictures of the student's ability, pinpoints the strong and weak areas in language teaching and learning. So the teaching and assessment always go hand and one has no relevance in the absence of another.
No -one can deny the importance of assessment and testing in language education program.

According to the theory of social interactionism, learning is an ongoing process in which the individual interacts with the environment (Boonyarattanasoontorn, 2017; Vygotsky, 1980). From the perspective of social interactionists developed the idea of the Zone of Proximal Development (ZPD) which classified on what they (learners) find comfortable themselves and what do they ignore in the process of learning. The following three conditions in the process of learning:

i) Comfort zone: There will always be conditions in which learners can handle the process of learning independently without any assistance.

ii) Zone of proximal development: In such conditions, learners can learn under the guidance which often happens in the form of meaningful interaction with the teacher or other learners who have already obtained the skills.

iii) Danger zone: in these conditions, learners cannot learn even with assistance.

It is clear that learning is possible with the help of teachers, peers, and parents and their continuous assessment especially what has already been learned, what can be learned, and what will have to wait to be learned. Therefore, assessment is a constant process in the language classrooms. The teacher follows several modes of assessment, i. e formative and summative assessment. The teacher always looks for achievement after experiencing some instruction. The focus is shifted to the process of learning whereby assessment occurs continuously and formatively while the learner is still learning (Stiggins, 2002). Thus, assessment is there for learning as the students are in the process of learning. Testing or assessment play vital role in effective learning and teaching. We can state that testing has always been an inherent part of teaching. Testing and teaching are two inseparable parts of educational programs because one could be meaningless in the absence of another. This can hardly ever be separated. Teaching and assessments can function like the combination of a pick and shovel to dig into language education. There are two $\mathrm{n}$ traffic relationship between language teaching and testing regarding to their influence to each other depending upon purposes .Assessment is the most important part of teaching and learning process because it is the process by which all elements of teaching and learning are affected .Assessment helps a teaching a to get feedback about this teaching and student's learning. It provides goals for language teaching and it monitors both teachers and learners for achieving to those goals. 


\section{Significance of this Study}

The steps of assessments can be continuously applied in both student-centered language classroom and traditional teacher-centered classrooms. Learners are supposed to participate actively in the process of learning-teachingassessment. Learners frequently test their own performance and progress with or without self-assessment checklists. They are also expected to assess their peers' works as well as their teachers' performance. It is important to know that the way in which the students understand assessment influences their quality of learning. If learners carry misconceptions about assessment, their learning and their peers' learning will not effective.

It is more important because it is integrated with day to day teaching and learning directly involving teachers. It also reduces the risk of over dependence in the process of assessment. It is based on the academic principal it is the teachers who keep close look on students learning and thereby could best judge their performance. It can promote adaptive learning behavior, when learners believe that it provides useful information on their learning needs and progress; however, it may cause maladaptive behavior if learners fail to see its relevance to their learning and development (Brown, 2004). From this viewpoint, it seems logical to argue how learners behave before, during, and after assessment depends on how they conceive of it (Segers, Dochy, \& Cascallar, 2006).

Therefore, it is relevant to understand students' perceptions regarding assessment. Research is needed to investigate what assessment means to learners. Such studies can provide invaluable information based on which more effective activities and teaching plans in the implementation level. Hence, this study is significant as its findings will provide useful implication for teachers, schools, parents, and stakeholders of education.

\section{Objective and Research Questions}

The major aim of the study was to explore a group of undergraduate students' perceptions of language assessment or testing. More specifically, the following research questions are addressed:

i) What do the undergraduate students understand by the purpose of language testing or assessment based on their experiences?

ii) What major themes emerge as a result of analyzing the short paragraph written by the undergraduate students about language assessment?

\section{REVIEW OF RELATED LITERATURE}

In the related literature, there has been conducted a number of researches related language testing skills, (Dawadi, 2018) interviews with English teachers in Nepal investigated that the testing of listening and speaking skills in examinations had a strong connection with their motivation for learning the English language. Likewise, Rubin, Daly, McCroskey, and Mead (1982) suggest that well-managed assessment practice can have a desirable effect on teachers' instructional activities and test achievements can have a progressive function in students' learning.

However, others (Khaniya, 2005; Liu, 2009) argue that there are many reasons, such as the use of local and national languages in the English language classroom, educational policy of the country and school environment, which influence teaching and learning of foreign languages including the English. Brown and Hirschfeld (2008) studied secondary school students' $(n=3469)$ conducted the Structural Equation Modeling (SEM) for understanding of assessment in New Zealand. It reported that indicated that lower reading achievement scores were predicted for nonmajority ethnicity students, male students, those who conceived of assessment as a measure of school accountability, those who ignored assessment, and those who conceived of assessment as fun.

The study by , Brown (2004) examined 760 Iranian university students' conceptions of assessment, using Confirmatory Factor Analysis (CFA). The results showed that students had both positive and negative conceptions of assessment. They regarded it as what can both improve learning-teaching and impede learner development.

Similarly, Razavipour and Rezagah (2018) conducted a focus group discussion with four teachers and also examined several teacher-made tests. Their results indicated that (i) teachers have not taken ownership of the reform, (ii) schools lack adequate resources, (iii) accountability demands have resulted in grade inflation, and (iv) teachers tend to be unable to assess consistently with the LAR demands. More specifically, Razavipour and Rezagah (2018) found that teachers appeared to be unclear about what and why they assessed; the teachers also found it difficult to align their assessment practices with principles of communicative language teaching method. Such findings indicate the need for developing language teachers' language assessment literacy to ensure that they comprehend the idea of language assessment reform and soften the ways to adjust with the accessible environment. 
Tong and Adamson (2015) conducted a survey on 423 and semi-structured interviews on 45 secondary school students' perceptions of school-based assessment in Hong Kong. The research findings indicated that that most of the students provided negative conceptions of the assessment and were dissatisfied with the insufficient feedback from their teacher. However, they agreed that feedback helped their learning.

The related reviews of literature mentioned above illustrates, studies on language learners' conceptions of assessment or testing still need the improvement in the context of Nepal. Furthermore, most of the past studies followed quantitative methods. It would be able to contribute once the emphasis is given on qualitative research in order to depict the cases of language testing or assessments effectively.

\section{METHODS AND PARTICIPANTS OF THE STUDY}

The researcher conducted case study, the data were collected and analyzed the data with the help of qualitative research approach. In this section, I have described the participants as well as the data collection and analysis methods. An intact group of B.Ed second year students were selected as the research participants which consisted of 12 in number studying under the Faculty of Education specialized in major English at Mahendra Ratna Campus (TU), Tahachal, Kathmandu Nepal. Most of them were males $(n=8)$. They represented from different parts of the country, These students had enrolled in a bachelor's degree course in the area of Language Education. About one third of the students were full time students. Most of the participants who were not job holder and depended to the parents for their expanses in order to live in Kathmandu, the capital city of the country.

\section{Data Collection}

The data were collected from an intact group of B.Ed second year students who had enrolled in a course on language education. The participants completed the first task in the first week. The task prompted the participants to complete the tasks.They were assigned to write a paragraph in two themes on how do they perceive about the assessments performed by the teachers and write about their experiences about it. In the related literature, responses have been analyzed by previous researchers to explore what individuals conceive of an assessment including their experiences. In the present study, the responses had been collected and analyzed for the purpose of exploring the perceptions on language testing and assessment.

The second theme involved writing experiences in they which presented their own (participants)' personal experiences of language assessment. The participants were given 1 week to complete this task. They read some sample stories related to English language assessment. It was collected and analyzed based on their experiences about the assessment on language Finally; the collected data consisted of 12 samples of experiences and paragraphs written by the participants.

\section{Data Analysis}

The data were analyzed qualitatively via thematic analysis. To analyze the perceptions and to address the first research question, deductive coding method was followed. The responses were analyzed based on Fulcher (2013), who outlines four broad purposes for language tests:

Tests are conducted for gatekeeping, empowering, motivating, and guiding. In addition to their purpose to help institutions to control their policies, employment, intake, etc., tests may also be used to empower or create equity in the community such as TOEFL and IELTS. Tests are given to the whole population and only those who perform better are given the opportunity to further their studies. Tests also motivate students to overlearn and internalize the material. Finally, tests can also guide stakeholders, which may happen in four different ways. First, tests can provide useful information which enables decision makers to select the right individuals for the suitable positions. Second, the right individuals can be placed in classes with different levels based on their performance in placement tests. Third, tests can also show how much the learner has achieved after some treatment. Finally, tests can also help teachers diagnose their learners' specific needs and areas of difficulty. It is clear that the role of test is inevitable in the field of Education, Business, Politics, Law, Linguistics and so on.

This information provided the present researchers with a useful analytical framework according to which the responses written by the participants could be analyzed and classified. Furthermore, this study also aimed at investigating the participants' experiences with language assessment by analyzing their short paragraphs and stories. It was adopted inductive coding in order to reach the purpose. The researchers read the stories, paragraphs and interpreted in to themes. The themes were coded as the participants' experiences. Then, the stories, paragraphs with similar themes were identified and the results indicated the frequency of occurrence of each theme across all the stories and paragraphs. 


\section{DISCUSSION}

There is empirical research evidence that the way learners conceive assessment determines their final achievement (Brown \& Hirschfeld, 2008). Thus, it is important to explore learners' perceptions of assessment. In the current study, a group of B.Ed second year students' conception of language assessment was investigated via the analysis of their paragraphs and short stories. As the analysis of the paragraphs showed, the participants in the current study covered all the purposes outlined by Fulcher (2013) especially in the field of language education. Therefore, it is easy to conclude that these participants are not completely aware of the purposes of language assessment. One possible reason could be these participants' relatively low assessment literacy as B.Ed second year students of major English Language Education. Another explanation for the participants' ideas on assessment could be noted that the students form multiple backgrounds (community and institutional background) ,educational, cultural, geographical issues to reflect the experiences teaching and assessing English as a second or foreign language by the teachers at the campus.

The results also showed (Nimehchisalem \& Hussin, 2018). that one of the purposes that had the lowest frequency was "to empower." It can be inferred from this result that the participants come from different backgrounds in which assessment is conceived as a testing rather than a learning tool. Our findings are in line with those of previous studies by Azis (2012), Cheng, Rogers, and Wang (2008), Remesal and Brown (2015) where grades were perceived as the indicator of students' success, and assessment made students so competitive that they made every attempt to obtain higher marks or grades rather than trying to improve their learning and understanding of the subject matter. These results also are in line with the themes which emerged from most of the paragraphs in which assessment as one of the cheating, anxiety, and prejudice, and also not able to function as a means that promotes collaboration and improvement. The results also corroborated those of Tong and Adamson (2015) survey in Hong Kong, who reported students' negative conceptions of and dissatisfaction with assessment practices in their respective educational system. In the present study , the respondents also agreed that feedback encouraged in their learning effectively. The analysis of the paragraph in my study also indicated the usefulness of formative and formative assessment which described for particular areas of difficulty faced by learners.

When I talk about the responses about the paragraphs and its analysis showed that very few (3out of 9) responses created by the participants presented negative conceptions toward assessment. On the other hand, as the paragraph data indicated, most ( 2 out of 3 ) of the paragraph represented negative themes about testing and assessment There are some reasons the participants could not notice to ongoing testing practices rather thy represented the possible explanation which could the effect of the language testing course that the participants were experiencing. As the course continued, they gained better understanding of assessment and how far assessment practices that they had experienced were far from ideal in their academic journey. Therefore, their views toward assessment practices varied from one batch to next and could have become more critical about the way assessment is typically practiced in their communities.

\section{CONCLUSION}

The objective of the present study was to explore a group of B.Ed second year students' conceptions of language assessment by analyzing a paragraph that they wrote about assessment individually. Based on the analysis of the paragraph written by the participants of this study, it was found that assessment is beneficial for teachers guide, motivate, control, and empower their learners. They viewed assessment as a means of accountability and improvement, it often encouraged for adaptive behavior in learners and supported in their learning. we can understand from the results that very few participants considered assessment an empowering tool. This implies that steps need to be taken to promote assessment for effective learning knowing the assessment that learners' perceptions change about assessment and more learners understand assessment as a tool in service of learning.

The results of analysis of paragraphs lead us to conclude that process-oriented and progressive assessments tend to adopt the several behavior and success stories of the students. The formative and summative forms of assessments or tests can result for the manipulative behaviors in language learning. Based on constructivist approach to learning, presented earlier in this paper and based on the current results, it can be concluded that effective assessment.

i) Is ongoing and progressive

ii) Motivates learners to excel

iii) Promotes collaborative learning; and

iv) Helps learners and teachers diagnose areas of difficulty. In addition, it can also be concluded that inadequate assessment:

i) Is unfair

ii) Is culturally biased

iii) Urges learners to cheat 
iv) Causes fear and anxiety

v) Causes failure and suicide

vi) Results in biased judgment

vii) Only considers the end-product

viii)Becomes an unfair gate-keeping tool

ix)Encourages the teacher to teach to the test

$\mathrm{x}$ )Leaves the teacher blind to what the learner is going through.

It is interesting to know that, in four responses, cheating was the result of unfair assessment practices. Teachers' malpractice entails and, interestingly, justifies students' unacceptable behavior. They urged that the prime goal of any educational system must develop for students. If our assessment lacks fairness, reliability, and validity, it will encourage cheating. Again, all the success paragraphs, assess- ment motivated and emphasized for effective learning. In one particular paragraph, a good student, who is under extensive pressure to succeed, fails a test, and therefore, she decides to leave the campus just because of unfair means while assessment. This suggested that the cooperation with community regarding the drop out of the students. More support should be provided by the educational systems for the community to deal with its misconception of failure.

\section{LIMITATIONS AND RECOMMENDATIONS}

This study is limited in scope as it investigated perceptions of students from Mahendra Ratna Campus, (TU) Tahachal, Kathamndu, Nepal only. This might limit the generalizability of results. Future research with different sample and different institutes is encouraged.

\section{REFERENCES}

Azis, A. (2012). Teachers'conceptions and use of assessment in student learning. Indonesian Journal of Applied Linguistics, 2(1), 40-52. doi:https://doi.org/10.17509/ijal.v2i1.72

Boonyarattanasoontorn, P. (2017). An investigation of thai students' English language writing difficulties and their use of writing strategies. Journal of Advanced Research in Social Sciences and Humanities, 2(2), 111-118. doi:https://doi.org/ 10.26500/jarssh-02-2017-0205

Brown, G. T. (2004). Teachers' conceptions of assessment: Implications for policy and professional development. Assessment in Education: Principles, Policy \& Practice, 11(3), 301-318. doi:https://doi.org/10.1080/0969594042000304609

Brown, G. T., \& Hirschfeld, G. H. (2008). Students' conceptions of assessment: Links to outcomes. Assessment in Education: Principles, Policy \& Practice, 15(1), 3-17. doi:https://doi.org/10.1080/09695940701876003

Cheng, L., Rogers, W. T., \& Wang, X. (2008). Assessment purposes and procedures in ESL/EFL classrooms. Assessment \& Evaluation in Higher Education, 33(1), 9-32.

Dawadi, S. (2018). The impact of the school leaving certificate examination on English language teaching and student motivation to learn English. London, UK: British Council.

De Jong, N. H. (2018). Fluency in second language testing: Insights from different disciplines. Language Assessment Quarterly, 15(3), 237--254. doi:https://doi.org/10.1080/15434303.2018.1477780

Fulcher, G. (2013). Practical language testing. London, UK: Routledge.

Heaton, J. B. (1975). Writing English language tests: A practical guide for teachers of English as a second or foreign language. Boston, MA: Addison-Wesley Longman Limited.

Hilao, M. P. (2016). Creative teaching as perceived by English language teachers in private universities. Journal of Advances in Humanities and Social Sciences, 2(5), 278-286. doi:https://doi.org/10.20474/jahss-2.5.4

Huges, A. (1995). Teaching and language teacher. London, UK: Oxford OUP.

Khaniya, T. (2005). Examination for enhanced learning. Lalitpur, India: Millennium Publication (P) Ltd.

Liu, T.-Y. (2009). A context-aware ubiquitous learning environment for language listening and speaking. Journal of Computer Assisted Learning, 25(6), 515-527. doi:https://doi.org/10.1111/j.1365-2729.2009.00329.x

Nimehchisalem, V., \& Hussin, N. I. S. M. (2018). Postgraduate students' conception of language assessment. Language Testing in Asia, 8(1), 1-14. doi:https://doi.org/10.1186/s40468-018-0066-3

Razavipour, K., \& Rezagah, K. (2018). Language assessment in the new English curriculum in Iran: Managerial, institutional, and professional barriers. Language Testing in Asia, 8(1), 9-15. doi:https://doi.org/10.1186/s40468-018-0061-8

Remesal, A., \& Brown, G. T. (2015). Conceptions of assessment when the teaching context and learner population matter: Compulsory school versus non-compulsory adult education contexts. European Journal of Psychology of Education, 30(3), 331-347. 
Rubin, D. L., Daly, J., McCroskey, J. C., \& Mead, N. A. (1982). A review and critique of procedures for assessing speaking and listening skills among preschool through grade twelve students. Communication Education, 31(4), 285-303. doi: https://doi.org/10.1080/03634528209384697

Segers, M., Dochy, F., \& Cascallar, E. (2006). Optimising new modes of assessment: In search of qualities and standards. California, CA: Kluwer Academic Publishers.

Stiggins, R. J. (2002). Assessment crisis: The absence of assessment for learning. Phi Delta Kappan, 83(10), 758-765. doi:https://doi.org/10.1177/003172170208301010

Tong, S. Y. A., \& Adamson, B. (2015). Student voices in school-based assessment. Australian Journal of Teacher Education, 40(2), 2-10. doi:https://doi.org/10.14221/ajte.2015v40n2.2

Vygotsky, L. S. (1980). Mind in society: The development of higher psychological processes. London, UK: Harvard university press.

Wu, A. A. (2017). A study on learning achievement of integrated songs of Chinese history dynasties into Chinese language teaching at third grade in junior college. International Journal of Humanities, Arts and Social Sciences, 3(5), 192-196. doi:https://doi.org/10.20469/ijhss.3.20001-5 